\title{
HUBUNGAN SARANA SANITASI RUMAH DAN PERILAKU HIDUP BERSIH DAN SEHAT DENGAN KEJADIAN DIARE PADA BALITA DI WILAYAH KERJA PUSKESMAS I KEMBARAN KABUPATEN BANYUMAS
}

\author{
Richani Ulfa Diyanti $^{1)}$, Choiroel Anwar ${ }^{1)}$, Asep Tata Gunawan ${ }^{1)}$ \\ 1) Poltekkes Kemenkes Semarang
}

\begin{abstract}
Abstrak
Latar belakang Jumlah penderita diare di wilayah kerja Puskesmas I Kembaran masuk ke dalam 10 besar jumlah penderita penyakit terbanyak.Pada tahun 2016 terdapat kasus diare sebanyak 813 kasus diare.Tujuan penelitian untuk mengetahui hubungan sarana sanitasi lingkungan dan perilaku hidup bersih dan sehat (PHBS) dengan kejadian diare pada balita di Wilayah Kerja Puskesmas I Kembaran Kabupaten Banyumas Tahun 2018.Jenis penelitian yang digunakan analitik dengan pendekatan case control. Jumlah sampel sebanyak 66 sampel, 22 sampel sebagai kasus dan 44 sampel sebagai kontrol. Variabel yang diteliti yaitu sarana air bersih, sarana pembuangan tinja/ jamban, sarana pembuanan air limbah, penyimpanan makanan dan minuman, menggunakan air bersih, membuang tinja bayi dan cuci tangan pakai sabun. Analisis dengan uji chi square, regresi logistik, dan OR dengan CI 95\% dan $\alpha 0,05$. Hasil analisis bivariat didapatkan sarana sanitasi lingkungan dan perilaku hidup bersih dan sehat yang memiliki hubungan yaitu sarana air bersih $(\mathrm{p}=0,000 ; \mathrm{OR}=19,741)$, sarana pembuangan tinja/jamban $(\mathrm{P}=0,000 ; \mathrm{OR}=11,327)$, penyimpanan makanan dan minuman $(\mathrm{p}=0,000 ; \mathrm{OR}=14,095)$, menggunakan air bersih $(\mathrm{p}=0,002 ; \mathrm{OR}=7,800)$, membuang tinja bayi $\mathrm{p}=0,001 ; \mathrm{OR}=7,286)$, cuci tangan pakai sabun $(p=0,006 ; O R=6,923)$. Sedangkan sarana pembuangan air limbah tidak memiliki hubungan yang signifikan dan tidak berisiko. Analisis multivariat menunjukkan variabel yang paling berpengaruh adalah sarana air bersih $(p=0,003 ; R P=10,663)$.Kesimpulan dari penelitian ini adalah sarana sanitasi lingkungan dan perilaku hidup bersih dan sehat dapat menjadi faktor risiko terjadinya penyakit diare. Variabel yang memiliki pengaruh paling signifikan yaitu sarana pembuangan tinja/jamban.Disarankan agar masyarakat selalu menjaga kebersihan lingkungan dan menerapkan perilaku hidup bersih dan sehat.
\end{abstract}

Kata Kunci: Sarana Sanitasi rumah, Diare, Balita

\begin{abstract}
[The Relationship Between Home Sanitation Facilities And Clean Living Behavior With Diarrhea Case Toward Toddler In The Working Area Of Health Center I Kembaran Banyumas Regency In Year 2018] The number of diarrhea sufferers in the working area of Puskesmas I Kembaran is included in the top 10 most people with disease. Thus, there are 813 diarrhea cases found in 2016. This study aims to determine the relationship between environmental sanitation facilities and clean healthy living behavior (PHBS) with diarrhea cases in the working areaof Puskesmas I KembaranBanyumas regency 2018. Type of research used in this research is analytical with case control approach. There are 66 samples where 22 samples are as case and 44 samples are as control. The variables studied are clean water, disposal facility / latrine, wastewater storage facilities, food and beverage storage, clean water use, disposing of baby's feces and hand washing with soap. Further, the research is analyzed with chi square test, logistic regression, and OR with $95 \% \mathrm{CI}$ and $\alpha 0,05$. The result of bivariate analysis was obtained by means of environmental sanitation and hygiene and hygienic living behavior which have relation of clean water facilities ( $p=0,000, O R=19,741)$, disposal facility $(P=0,000 ; O R=11,327)$, food and beverage storage $p=0,000 ; O R=14,095)$, the use of clean water $(p=0,002 ; O R=7,800)$, removing infant stool $p=0,001 ; O R=7,286)$, handwashing with soap $(p=0,006 ; O R=6,923)$. While the waste water disposal facilities have no significant relationship and are not at risk. However, the multivariate analysis shows that the most influential variable is clean water $(p=0,003 ; R P=10,663)$. This research can be concluded that environmental sanitation and clean healthy life behavior can be a
\end{abstract}


risk factor for diarrheal disease. The variable which has the most significant influence is the disposal of feces / latrines. It is recommended that the public always maintain the cleanliness of the environment and apply clean and healthy living behavior.

Keywords: Home Sanitation Facilities, Diarrhea, Toddler

\section{Pendahuluan}

Kesehatan menunjukkan bahwa diare menjadi pembunuh nomor satu penyebab kematian berdasarkan umur pada anak balita atau kelompok umur 1 - 4 tahun. (Kemenkes RI, 2011). Disamping itu, menurut hasil Riskesdas tahun 2007 menunjukkan bahwa penyakit diare merupakan penyebab utama kematian pada balita. Target MDG,s ke-4 adalah penurunan kematian anak dari tahun 1990 menjadi 2/3 bagian sampai 2015. Salah satu upaya untuk menurunkannya adalah dengan menurunkan kematian karena diare. (Kemenkes RI, 2011).

Di Indonesia diare masih merupakan salah satu masalah kesehatan masyarakat.Diare didefinisikan sebagai perubahan konsistensi feses dan perubahan frekuensi buang air besar lebih dari 3 kali dalam sehari. Penyakit ini dapat juga didefinisikan bila buang air besar tiga kali atau lebih dan buang air besar yang berair tapi tidak berdarah dalam waktu 24 jam (Departemen Kesehatan RI, 2009). Salah satu penyebab dari terjadinya diare adalah faktor lingkungan dan perilaku.

Proporsi kasus diare di Jawa Tengah tahun 2015 sebesar $(67,7 \%)$. Untuk kasus berdasarkan gender antara laki-laki dan perempuan lebih banyak perempuan, hal ini disebabkan bahwa perempuan lebih banyak berhubungan dengan faktor risiko diare, yang penularannya melalui vekal oral, terutama berhubungan dengan sarana air bersih, cara penyediaan makanan dan Perilaku Hidup Bersih dan sehat (PHBS). (Profil Kesehatan Provinsi Jawa Tengah Tahun 2015).

Diare merupakan Penyakit Endemis di Kabupaten Banyumas dan merupakan penyakit potensial KLB yang sering disertai dengan kematian terutama pada daerah yang pengendalian faktor resikonya masih rendah. Kasus Diare di Kabupaten Banyumas dari tahun ke tahun masih tetap tinggi dibanding dengan kasus penyakit lainnya. Angka kesakitan diare Kabupaten Banyumas tahun 2014 adalah 214/1000 penduduk, sedangkan pada tahun 2013 adalah 21,55 /1000 penduduk. (Profil Kesehatan Kabupaten Banyumas Tahun 2014). Jumlah penderita diare di wilayah kerja Puskesmas I Kembaran masuk ke dalam 10 besar jumlah penderita penyakit terbanyak.Pada tahun 2016 terdapat kasus diare sebanyak 813 kasus diare.

Disamping tingginya kasus diare, di wilayah kerja Puskesmas I kembaran juga masih memiliki akses jamban yang rendah.Tahun 2017 dari jumlah KK yang ada yaitu 10.989 yang masih belum memiliki jamban sebanyak 5.237 KK.Dan masih terdapat penduduk yang melakukan buang air besar sembarangan (BABS) yaitu sebanyak 2789.Melihat tingginya kasus diare pada balita dan rendahnya akses jamban serta tingginya angka BABS di wilayah kerja Puskesmas I Kembaran, penulis tertarik untuk melakukan penelitian di desa tersebut yaitu dengan judul penelitian "Hubungan Sarana Sanitasi Rumah Dan Perilaku Hidup Bersih dan Sehat dengan Kejadian Diare Pada Balita Di Wilayah Kerja Puskesmas I Kembaran Kabupaten Banyumas Tahun 2018".

Perumusan masalah pada penelitian ini adalah Apakah Ada Hubungan Sarana Sanitasi Rumah dan Perilaku Hidup Bersih dan Sehat dengan Kejadian Diare Pada Balita Di Wilayah Kerja Puskesmas I Kembaran Kabupaten Banyumas 2018?

Tujuan penelitian adalah Mengetahui hubungan sarana sanitasi rumah dan perilaku hidup bersih dan sehat yang mempengaruhi kejadian penyakit diare pada balita di Wilayah kerja Puskesmas I Kembaran.

\section{Bahan dan Metode}

Jenis penelitian ini menggunakan desain Case Control suatu penelitian (survei) yangmenyangkut bagaimana faktor risiko dipelajari dengan menggunakan pendekatan retrospective. Dengan kata lain, efek (penyakit atau status kesehatan) diidentifikasi pada saat ini, kemudian faktor risiko diidentifikasi ada atau terjadinya pada waktu yang lalu (Prof. Dr. Soekidjo Notoatmodjo, 2010). Jumlah sampel sebanyak 66 sampel, 22 sampel sebagai kasus dan 44 sampel sebagai kontrol. Populasi adalah semua balita yang berobat ke Puskesmas I Kembaran pada bulan Desember 2017 yang didiagnosis terkena Diare oleh dokter Puskesmas.Teknik pengambilan sampel menggunakan purposive sampling.

Variable bebas adalah variabel yang berpengaruh dan menyebabkan berubahnya variabel terikat.Variabel bebas dalam penelitian ini adalah sarana air bersih, sarana pembuangan tinja (jamban), sarana pembuangan air limbah, sarana penyimpanan makanan dan minuman dan Perilaku Hidup Bersih dan Sehat. Variabel terikat adalah variabel yang diduga nilainya akan berubah karena adanya pengaruh dari variable bebas. Variable terikat dalam penelitian ini adalah kejadian diare pada balita di Wilayah kerja Puskesmas I Kembaran Kabupaten Banyumas Tahun 2018.

Cara pengumpulan data : Alat pengumpulan data menggunakan checklist untuk observasi sarana yang digunakan responden dan kuesioner untuk wawancara responden. Hasil observasi dan 
wawancara dianalisis menggunakan soft ware analisis data yang terdiri dari analisis univariate untuk mendeskripsikan karakteristik setiap variabel penelitian, analisis bivariate menggunakan uji chi square untuk mengetahui apakah variabel bebas dan variabel terikat ada hubungannya dan analisis multivariate menggunakan uji regresi logistik untuk mengetahui variabel independen manakah yang paling berpengaruh hubungannya dengan variabel dependen.

\section{Hasil dan Pembahasan}

a. Analisis Univariat

1) Sarana Air Bersih pada Kelompok Kasus

\begin{tabular}{|c|c|c|c|}
\hline \multirow[t]{2}{*}{ No } & \multirow[t]{2}{*}{ Sarana Air Bersih } & \multicolumn{2}{|c|}{ Kasus } \\
\hline & & $\mathrm{N}$ & $\%$ \\
\hline 1 & $\begin{array}{l}\text { Tidak Memenuhi } \\
\text { Syarat }\end{array}$ & 13 & 59,1 \\
\hline 2 & Memenuhi Syarat & 9 & 40,9 \\
\hline Tot: & & 22 & 100 \\
\hline
\end{tabular}

Berdasarkan tabel di atas Sarana air bersih dalam kelompok kasus menunjukkan bahwa dari 22 responden yang menderita diare terdapat $13(59,1 \%)$ responden yang memiliki sarana air bersih tidak memenuhi syarat dan 9 $(40,9 \%)$ responden memiliki sarana air bersih memenuhi syarat.

2) Sarana Air Bersih pada Kelompok Kontrol

\begin{tabular}{llll}
\hline \multirow{2}{*}{ No } & Sarana Air Bersih & \multicolumn{2}{c}{ Kontrol } \\
\cline { 3 - 4 } & & $\mathrm{N}$ & $\%$ \\
\hline 1 & $\begin{array}{l}\text { Tidak Memenuhi } \\
\text { Syarat }\end{array}$ & 3 & 6,8 \\
2 & Memenuhi Syarat & 41 & 93,2 \\
\hline Total & 44 & 100
\end{tabular}

Berdasarkan tabel di atas Sarana air bersih dalam kelompok kontrol menunjukkan bahwa dari 44 responden yang menderita diare terdapat $3(6,8 \%)$ responden yang memiliki sarana air bersih tidak memenuhi syarat dan 41 $(93,2 \%)$ responden memiliki sarana air bersih memenuhi syarat.

3) Sarana Pembuangan Tinja (Jamban) pada Kelompok Kasus

\begin{tabular}{llcc}
\hline No & $\begin{array}{l}\text { Sarana } \\
\text { Pembuangan } \\
\text { Tinja (Jamban) }\end{array}$ & $\mathrm{N}$ & $\%$ \\
\cline { 2 - 3 } 1 & $\begin{array}{l}\text { Tidak Memenuhi } \\
\text { Syarat }\end{array}$ & 15 & 68,2 \\
2 & Memenuhi Syarat & 7 & 31,8 \\
\hline Total & 22 & 100 \\
\hline
\end{tabular}

Berdasarkan tabel di atas Sarana pembuangan tinja (jamban) dalam kelompok kasus menunjukkan bahwa dari 22 responden yang menderita diare terdapat $15 \quad(68,2 \%)$ responden yang memiliki sarana pembuangan tinja (jamban) tidak memenuhi syarat dan 7 $(31,8 \%)$ responden memiliki sarana pembuangan tinja (jamban) memenuhi syarat.

4) Sarana Pembuangan Tinja (Jamban) pada Kelompok Kontrol

\begin{tabular}{llcc}
\hline No & $\begin{array}{l}\text { Sarana } \\
\text { Pembuangan } \\
\text { Tinja (Jamban) }\end{array}$ & N & Kontrol \\
\cline { 2 - 3 } & Tidak & 7 & 15,9 \\
& $\begin{array}{l}\text { Memenuhi } \\
\text { Syarat }\end{array}$ & 37 & 84,1 \\
2 & $\begin{array}{l}\text { Memenuhi } \\
\text { Syarat }\end{array}$ & 34 & 100
\end{tabular}

Berdasarkan tabel di atas Sarana pembuangan tinja (jamban) dalam kelompok kontrol menunjukkan bahwa dari 44 responden yang menderita diare terdapat $7(15,9 \%)$ responden yang memiliki sarana pembuangan tinja (jamban) tidak memenuhi syarat dan 37 $(84,1 \%)$ responden memiliki sarana pembuangan tinja (jamban) memenuhi syarat.

5) Sarana Pembuangan Air Limbah pada Kelompok Kasus

\begin{tabular}{|c|c|c|c|}
\hline \multirow[t]{2}{*}{ No } & \multirow{2}{*}{$\begin{array}{l}\text { Sarana } \\
\text { Pembuangan } \\
\text { Air Limbah }\end{array}$} & \multicolumn{2}{|c|}{ Kasus } \\
\hline & & $\mathrm{N}$ & $\%$ \\
\hline 1 & $\begin{array}{l}\text { Tidak } \\
\text { Memenuhi } \\
\text { Syarat }\end{array}$ & 19 & 86,4 \\
\hline 2 & $\begin{array}{l}\text { Memenuhi } \\
\text { Syarat }\end{array}$ & 3 & 13,6 \\
\hline & Total & 22 & 100 \\
\hline
\end{tabular}

Berdasarkan tabel di atas Sarana pembuangan air limbah dalam kelompok kasus menunjukkan bahwa dari 22 responden yang menderita diare terdapat $19 \quad(86,4 \%)$ responden yang memiliki sarana pembuangan air limbah tidak memenuhi syarat dan 3 $(13,6 \%)$ responden memiliki sarana pembuangan air limbah memenuhi syarat. 
6) Sarana Pembuangan Air Limbah pada Kelompok Kontrol

\begin{tabular}{|c|c|c|c|}
\hline \multirow[t]{2}{*}{ No } & \multirow{2}{*}{$\begin{array}{l}\text { Sarana } \\
\text { Pembuangan Air } \\
\text { Limbah }\end{array}$} & \multicolumn{2}{|c|}{ Kontrol } \\
\hline & & $\mathrm{N}$ & $\%$ \\
\hline 1 & $\begin{array}{l}\text { Tidak } \\
\text { Memenuhi } \\
\text { Syarat }\end{array}$ & 40 & 90,9 \\
\hline 2 & $\begin{array}{l}\text { Memenuhi } \\
\text { Syarat }\end{array}$ & 4 & 9,1 \\
\hline & Total & 44 & 100 \\
\hline
\end{tabular}

Berdasarkan tabel di atas Sarana pembuangan air limbah dalam kelompok kontrol menunjukkan bahwa dari 44 responden yang menderita diare terdapat $40 \quad(90,9 \%)$ responden yang memiliki sarana pembuangan air limbah tidak memenuhi syarat dan 4 $(9,1 \%)$ responden memiliki sarana pembuangan air limbah memenuhi syarat.

7) Penyimpanan Makanan dan Minuman pada Kelompok Kasus

\begin{tabular}{llcc}
\hline No & $\begin{array}{l}\text { Penyimpanan } \\
\text { Makanan dan } \\
\text { Minuman }\end{array}$ & \multicolumn{2}{c}{ Kasus } \\
\cline { 2 - 4 } 1 & $\begin{array}{l}\text { Tidak Memenuhi } \\
\text { Syarat }\end{array}$ & 16 & 72,7 \\
2 & $\begin{array}{l}\text { Memenuhi } \\
\text { Syarat }\end{array}$ & 6 & 27,3 \\
\hline & $\quad$ Total & 22 & 100
\end{tabular}

Berdasarkan tabel di atas Penyimpanan makanan dan minuman dalam kelompok kasus menunjukkan bahwa dari 22 responden yang menderita diare terdapat $16(72,7 \%)$ responden yang memiliki tempat penyimpanan makanan dan minuman tidak memenuhi syarat dan $6(27,3 \%)$ responden memiliki tempat penyimpanan makanan dan minuman memenuhi syarat.

8) Penyimpanan Makanan Dan Minuman pada Kelompok Kontrol

\begin{tabular}{|c|c|c|c|}
\hline \multirow[t]{2}{*}{ No } & Penyimpanan & \multicolumn{2}{|c|}{ Kontrol } \\
\hline & $\begin{array}{l}\text { Makanan dan } \\
\text { Minuman }\end{array}$ & $\mathrm{N}$ & $\%$ \\
\hline 1 & $\begin{array}{l}\text { Tidak } \\
\text { Memenuhi } \\
\text { Syarat }\end{array}$ & 7 & 15,9 \\
\hline 2 & $\begin{array}{l}\text { Memenuhi } \\
\text { Syarat }\end{array}$ & 37 & 84,1 \\
\hline & Total & 44 & 100 \\
\hline
\end{tabular}

Berdasarkan tabel di atas Penyimpanan makanan dan minuman dalam kelompok kontrol menunjukkan bahwa dari 44 responden yang menderita diare terdapat 7 $(15,9 \%)$ responden yang memiliki penyimpanan makanan dan minuman tidak memenuhi syarat dan $37(84,1 \%)$ responden memiliki penyimpanan makanan dan minuman memenuhi syarat.

9) Perilaku Menggunakan Air Bersih pada Kelompok Kasus

\begin{tabular}{llcc}
\hline \multirow{2}{*}{ No } & Menggunakan Air & \multicolumn{2}{c}{ Kasus } \\
\cline { 2 - 4 } & Bersih & $\mathrm{N}$ & $\%$ \\
\hline 1 & $\begin{array}{l}\text { Tidak Memenuhi } \\
\text { Syarat }\end{array}$ & 11 & 50,0 \\
2 & Memenuhi Syarat & 11 & 50,0 \\
\hline & Total & 22 & 100 \\
\hline
\end{tabular}

Berdasarkan tabel di atas Perilaku menggunakan air bersih untuk kebutuhan sehari - hari dalam kelompok kasus menunjukkan bahwa dari 22 responden yang menderita diare terdapat $11 \quad(50,0 \%)$ responden yang memiliki perilaku menggunakan air bersih tidak baik dan 11 $(50,0 \%)$ responden memiliki perilaku menggunakan air bersih yang baik.

10) Perilaku Menggunakan Air Bersih pada Kelompok Kontrol

\begin{tabular}{|c|c|c|c|}
\hline \multirow[t]{2}{*}{ No } & \multirow{2}{*}{$\begin{array}{l}\text { Menggunakan } \\
\text { Air Bersih }\end{array}$} & \multicolumn{2}{|c|}{ Kasus } \\
\hline & & $\mathrm{N}$ & $\%$ \\
\hline 1 & $\begin{array}{l}\text { Tidak Memenuhi } \\
\text { Syarat }\end{array}$ & 5 & 11,4 \\
\hline 2 & Memenuhi Syarat & 39 & 88,6 \\
\hline & Total & 44 & 100 \\
\hline
\end{tabular}

Berdasarkan tabel di atas Perilaku menggunakan air bersih dalam kelompok kontrol menunjukkan bahwa dari 44 responden yang menderita diare terdapat 5 $(11,4 \%)$ responden yang memiliki perilaku menggunakan air bersih tidak baik dan 39 $(88,6 \%)$ responden memiliki perilaku menggunakan air bersih yang baik.

11) Perilaku Membuang Tinja Bayi pada Kelompok Kasus

\begin{tabular}{|c|c|c|c|}
\hline \multirow[t]{2}{*}{ No } & \multirow{2}{*}{$\begin{array}{l}\text { Membuang } \\
\text { Tinja Bayi }\end{array}$} & \multicolumn{2}{|c|}{ Kasus } \\
\hline & & $\mathrm{N}$ & $\%$ \\
\hline 1 & $\begin{array}{l}\text { Tidak Memenuhi } \\
\text { Syarat }\end{array}$ & 15 & 68,2 \\
\hline 2 & Memenuhi Syarat & 7 & 31,8 \\
\hline & Total & 22 & 100 \\
\hline
\end{tabular}

Berdasarkan tabel di atas Perilaku membuang tinja bayi dalam kelompok kasus menunjukkan bahwa dari 22 responden yang menderita diare terdapat $15 \quad(68,2 \%)$ responden yang memiliki perilaku membuang tinja bayi tidak baik dan $7(31,8 \%)$ responden memiliki perilaku membuang tinja bayi pada jamban yang saniter. 
12) Perilaku Membuang Tinja Bayi pada Kelompok Kontrol

\begin{tabular}{|c|c|c|c|}
\hline \multirow[t]{2}{*}{ No } & \multirow{2}{*}{$\begin{array}{l}\text { Membuang } \\
\text { Tinja Bayi }\end{array}$} & \multicolumn{2}{|c|}{ Kontrol } \\
\hline & & $\mathrm{N}$ & $\%$ \\
\hline 1 & $\begin{array}{l}\text { Tidak Memenuhi } \\
\text { Syarat }\end{array}$ & 10 & 22,7 \\
\hline 2 & Memenuhi Syarat & 34 & 77,3 \\
\hline
\end{tabular}

Berdasarkan tabel di atas Perilaku membuang tinja bayi dalam kelompok kontrol menunjukkan bahwa dari 44 responden yang menderita diare terdapat $10 \quad(22,7 \%)$ responden yang memiliki perilaku membuang tinja bayi tidak baik dan $34(77,3 \%)$ responden memiliki perilaku membuang tinja bayi pada jamban yang saniter.

13) Perilaku Cuci Tangan Pakai Sabun pada Kelompok Kasus

\begin{tabular}{llcc}
\hline \multirow{2}{*}{ No } & Cuci Tangan & \multicolumn{2}{c}{ Kasus } \\
\cline { 2 - 3 } & Pakai Sabun & $\mathrm{N}$ & $\%$ \\
\hline 1 & $\begin{array}{l}\text { Tidak Memenuhi } \\
\text { Syarat }\end{array}$ & 9 & 40,9 \\
2 & $\begin{array}{l}\text { Memenuhi } \\
\text { Syarat }\end{array}$ & 13 & 59,1 \\
\hline$\quad$ Total & 22 & 100 \\
\hline
\end{tabular}

Berdasarkan tabel di atas Perilaku cuci tangan pakai sabun dalam kelompok kasus menunjukkan bahwa dari 22 responden yang menderita diare terdapat $9(40,9 \%)$ responden yang memiliki perilaku cuci tangan pakai sabun tidak baik dan $13(59,1 \%)$ responden memiliki perilaku cuci tangan pakai sabun yang baik.

14) Perilaku Cuci Tangan Pakai Sabun pada Kelompok Kontrol

\begin{tabular}{clcc}
\hline No & Cuci Tangan & \multicolumn{2}{c}{ Kontrol } \\
\cline { 2 - 3 } & Pakai Sabun & N & $\%$ \\
\hline 1 & $\begin{array}{l}\text { Tidak } \\
\text { Memenuhi } \\
\text { Syarat }\end{array}$ & 4 & 9,1 \\
2 & $\begin{array}{l}\text { Memenuhi } \\
\text { Syarat }\end{array}$ & 40 & 90,9 \\
\hline & Total & 44 & 100 \\
\hline
\end{tabular}

Berdasarkan tabel di atas Perilku cuci tangan pakai sabun dalam kelompok kontrol menunjukkan bahwa dari 44 responden yang menderita diare terdapat $4(9,1 \%)$ responden yang memiliki perilaku cuci tangan pakai sabun tidak baik dan $40(90,9 \%)$ responden perilaku cuci tangan pakai sabun yang baik. b. Bivariat

1) Hubungan Sarana Air Bersih dengan Kejadian Diare Pada Balita

\begin{tabular}{lcccc}
\hline Sarana & air & \multicolumn{2}{c}{ Kasus } & \multicolumn{2}{c}{ Kontrol } \\
bersih & $\sum^{2}$ & $\%$ & $\sum$ & $\%$ \\
\hline Tidak & 13 & 59,1 & 3 & $6,8 \%$ \\
memenuhi & & $\%$ & & \\
syarat & & & & \\
Memenuhi & 9 & 40,9 & 41 & 93,2 \\
syarat & & $\%$ & & $\%$ \\
Total & 22 & 100 & 44 & 100 \\
& & $\%$ & & $\%$ \\
\hline P-value $: 0,000$ & OR : 19,741 & CI : 4,640 \\
$-83,983$ & & & & \\
\hline
\end{tabular}

Berdasarkan hasil penelitian menunjukkan bahwa sarana air bersih yang tidak memenuhi syarat pada kelompok kasus proporsi lebih besar $(59,1 \%)$ dibandingkan dengan kelompok kontrol $(6,8 \%)$, sedangkan sarana air bersih yang memenuhi syarat pada kelompok kontrol proporsi lebih besar $(93,2 \%)$ dibandingkan dengan kelompok kasus $(40,9 \%)$.

Hasil uji chi square menunjukkan nilai P-value 0,000 dengan demikian nilai P-value lebih kecil dari $\alpha: 0,05$ maka dinyatakan terdapat hubungan yang signifikan antara sarana air bersih dengan kejadian diare pada balita, pengujian odd ratio menunjukkan nilai $\mathrm{OR}$ : 19,741 (CI: 4,640 - 83,983) artinya responden yang saran air bersih tidak memenuhi syarat memiliki risiko dapat terkena diare 19,741 kali lebih besar dibandingkan dengan responden yang sarana air bersih memenuhi syarat.

2) Hubungan Sarana Pembuangan Tinja (Jamban) dengan Kejadian Diare Pada Balita

\begin{tabular}{|c|c|c|c|c|}
\hline \multirow{2}{*}{$\begin{array}{l}\text { Sarana } \\
\text { pembuang } \\
\text { an Tinja }\end{array}$} & \multicolumn{2}{|c|}{ Kasus } & \multicolumn{2}{|c|}{ Kontrol } \\
\hline & $\Sigma$ & $\%$ & $\Sigma$ & $\%$ \\
\hline $\begin{array}{l}\text { Tidak } \\
\text { memenuhi } \\
\text { syarat }\end{array}$ & 15 & $\begin{array}{c}68,2 \\
\%\end{array}$ & 7 & $\begin{array}{c}15,9 \\
\%\end{array}$ \\
\hline $\begin{array}{l}\text { Memenuhi } \\
\text { syarat }\end{array}$ & 7 & $\begin{array}{c}31,8 \\
\%\end{array}$ & 37 & $\begin{array}{c}84,1 \\
\%\end{array}$ \\
\hline Total & 22 & $100 \%$ & 44 & $100 \%$ \\
\hline $\begin{array}{l}\text { P-value } \\
37,879\end{array}$ & & 11,32 & 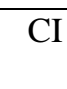 & $3,387-$ \\
\hline
\end{tabular}

Berdasarkan hasil penelitian menunjukkan bahwa sarana pembuangan tinja (jamban) yang tidak memenuhi syarat pada kelompok kasus proporsi lebih besar $(68,2 \%)$ dibandingkan dengan kelompok kontrol $(15,9 \%)$, sedangkan sarana pembuangan tinja (jamban) yang memenuhi syarat pada kelompok kontrol proporsi lebih besar $(84,1 \%)$ dibandingkan dengan kelompok kasus $(31,8 \%)$. 
Hasil uji chi square menunjukkan nilai P-value 0,000 dengan demikian nilai $\mathrm{P}$-value lebih kecil dari $\alpha: 0,05$ maka dinyatakan terdapat hubungan yang signifikan antara sarana pembuangan tinja (jamban) dengan kejadian diare pada balita, pengujian odd ratio menunjukkan nilai OR : 11,327 (CI : 3,387 37,879) artinya responden yang sarana pembuangan tinja (jamban) tidak memenuhi syarat memiliki risiko dapat terkena diare 11,327 kali lebih besar dibandingkan dengan responden yang sarana pembuangan tinja (jamban) memenuhi syarat.

3) Hubungan Sarana Pembuangan Air Limbah dengan Kejadian Diare pada Balita

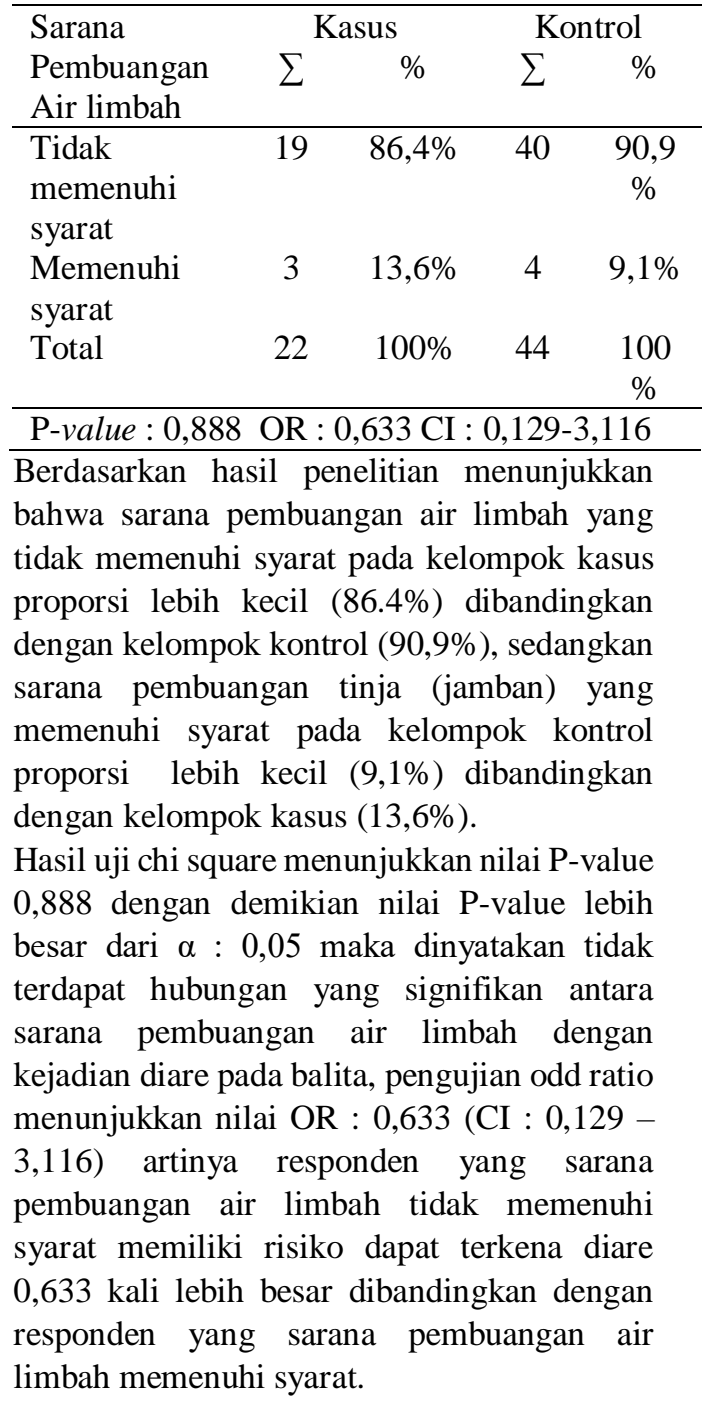

4) Hubungan Penyimpanan Makanan dan Minuman Dengan Kejadian Diare pada Balita

\begin{tabular}{lcccc}
\hline $\begin{array}{l}\text { Penyimpanan } \\
\text { makanan dan } \\
\text { minuman }\end{array}$ & \multicolumn{2}{c}{ Kasus } & \multicolumn{2}{c}{ Kontrol } \\
Tidak & $\%$ & $\sum$ & $\%$ \\
memenuhi & 16 & $72,7 \%$ & 7 & $\begin{array}{c}15,9 \\
\%\end{array}$
\end{tabular}

syarat

$\begin{array}{llllc}\begin{array}{l}\text { Memenuhi } \\ \text { syarat }\end{array} & 6 & 27,3 \% & 37 & 84,1 \\ \%\end{array}$

Total $22 \quad 100 \% \quad 44 \quad 100 \%$

P-value : 0,000 OR : 14,095 CI : 4,087 48,616

Berdasarkan hasil penelitian menunjukkan bahwa penyimpanan makanan dan minuman yang tidak memenuhi syarat pada kelompok kasus proporsi lebih besar $(72,7 \%)$ dibandingkan dengan kelompok kontrol $(15,9 \%)$, sedangkan penyimpanan makanan dan minuman yang memenuhi syarat pada kelompok kontrol proporsi lebih besar $(84,1 \%)$ dibandingkan dengan kelompok kasus $(27,3 \%)$.

Hasil uji chi square menunjukkan nilai $\mathrm{P}$-value 0,000 dengan demikian nilai $\mathrm{P}$-value lebih kecil dari $\alpha: 0,05$ maka dinyatakan terdapat hubungan yang signifikan antara penyimpanan makanan dan minuman dengan kejadian diare pada balita, pengujian odd ratio menunjukkan nilai OR : 14,095 (CI : 4,087 48,616 ) artinya responden yangpenyimpanan makanan dan minuman tidak memenuhi syarat memiliki risiko dapat terkena diare 14,095 kali lebih besar dibandingkan dengan responden yang penyimpanan makanan dan minuman memenuhi syarat.

5) Hubungan Perilaku Menggunakan Air Bersih dengan Kejadian Diare pada Balita

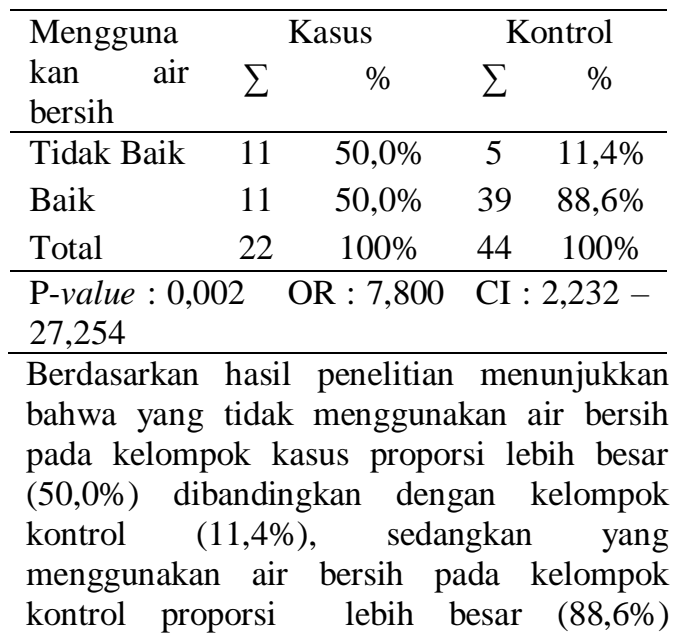


dibandingkan dengan kelompok kasus $(50,0 \%)$.

Hasil uji chi square menunjukkan nilai P-value 0,002 dengan demikian nilai $\mathrm{P}$-value lebih kecil dari $\alpha: 0,05$ maka dinyatakan terdapat hubungan yang signifikan antara perilaku menggunakan air bersih dengan kejadian diare pada balita, pengujian odd ratio menunjukkan nilai OR : 7,800 (CI : 2,232 - 27,254) artinya responden yang tidak menggunakan air bersih memiliki risiko dapat terkena diare 7,800 kali lebih besar dibandingkan dengan responden yang berperilaku menggunakan air bersih.

6) Hubungan Perilaku Membuang Tinja Bayi dengan Kejadian Diare pada Balita

\begin{tabular}{lcccc}
\hline Membuang & \multicolumn{2}{c}{ Kasus } & \multicolumn{2}{c}{ Kontrol } \\
tinja bayi & $\sum$ & $\%$ & $\sum$ & $\%$ \\
\hline Tidak Baik & 15 & $68,2 \%$ & 10 & $22,7 \%$ \\
Baik & 7 & $31,8 \%$ & 34 & $77,3 \%$ \\
Total & 22 & $100 \%$ & 44 & $100 \%$ \\
\hline P-value : 0,001 & OR : 7,286 & CI : $2,328-$ \\
22,805 & & & \\
\hline
\end{tabular}

Berdasarkan hasil penelitian menunjukkan bahwa yang tidak membuang tinja bayi ke jamban yang saniter pada kelompok kasus proporsi lebih besar $(68,2 \%)$ dibandingkan dengan kelompok kontrol (22,7\%), sedangkan yang membuang tinja bayi ke jamban yang saniter pada kelompok kontrol proporsi lebih besar $(77,3 \%)$ dibandingkan dengan kelompok kasus $(31,8 \%)$.

Hasil uji chi square menunjukkan nilai $\mathrm{P}$-value 0,001 dengan demikian nilai P-value lebih kecil dari $\alpha: 0,05$ maka dinyatakan terdapat hubungan yang signifikan antara perilaku membuang tinja bayi ke jamban yang saniter dengan kejadian diare pada balita, pengujian odd ratio menunjukkan nilai OR : 7,286 (CI : $2,328-22,805)$ artinya responden yang tidak membuang tinja bayi ke jamban yang saniter memiliki risiko dapat terkena diare 7,286 kali lebih besar dibandingkan dengan responden yang berperilaku membuang tinja bayi ke jamban yang saniter.

7) Hubungan Perilaku Cuci Tangan Pakai Sabun dengan Kejadian Diare pada Balita

\begin{tabular}{lcccc}
\hline Cuci tangan & \multicolumn{2}{c}{ Kasus } & \multicolumn{2}{c}{ Kontrol } \\
pakai sabun & $\sum$ & $\%$ & $\sum$ & $\%$ \\
\hline Tidak Baik & 9 & $40,9 \%$ & 4 & $9,1 \%$ \\
Baik & 13 & $59,1 \%$ & 40 & $90,9 \%$ \\
Total & 22 & $100 \%$ & 44 & $100 \%$ \\
\hline P-value : 0,006 OR: $6,923 \mathrm{CI}: 1,824-26,273$ \\
\hline
\end{tabular}

Berdasarkan hasil penelitian menunjukkan bahwa yang tidak cuci tangan pakai sabun pada kelompok kasus proporsi lebih besar (40,9\%) dibandingkan dengan kelompok kontrol $(9,1 \%)$, sedangkan yang cuci tangan pakai sabun pada kelompok kontrol proporsi lebih besar $(90,9 \%)$ dibandingkan dengan kelompok kasus $(59,1 \%)$.

Hasil uji chi square menunjukkan nilai P-value 0,006 dengan demikian nilai P-value lebih kecil dari $\alpha: 0,05$ maka dinyatakan terdapat hubungan yang signifikan antara perilaku cuci tangan pakai sabun dengan kejadian diare pada balita, pengujian odd ratio menunjukkan nilai OR : 6,923 artinya responden yang tidak cuci tangan pakai sabun memiliki risiko dapat terkena diare 6,923 kali lebih besar dibandingkan dengan responden yang berperilaku cuci tangan pakai sabun.

c. Multivariat

\begin{tabular}{clccc}
\hline No & Variabel & B & $\begin{array}{c}\text { Nilai } \\
\text { P- } \\
\text { value }\end{array}$ & $\begin{array}{c}\text { Exp.B } \\
\text { (RP) }\end{array}$ \\
\hline 1 & $\begin{array}{l}\text { Sarana } \\
\text { air bersih }\end{array}$ & $\begin{array}{c}2.36 \\
7\end{array}$ & 0,003 & 10,663 \\
& $\begin{array}{l}\text { Penyimp } \\
\text { anan }\end{array}$ & 2.08 & 0,003 & 8.058 \\
& 7 \\
& $\begin{array}{l}\text { makanan } \\
\text { dan } \\
\text { minuman }\end{array}$ & & & \\
& & & \\
\hline & Constan & -2.241 & 0,004 & 0,106 \\
\hline
\end{tabular}

Berdasarkan di atas menunjukkan bahwa terdapat dua variabel bebas yang memiliki pengaruh secara bersama-sama terhadap kejadian diare pada balita di Wilayah Kerja Puskesmas I Kembaran Kabupaten Banyumas yaitu sarana air bersih dengan nilai P-value : 0,003 lebih kecil dari $\alpha: 0,05$ dan nilai RP : 10,663 maka dinyatakan bermakna secara statistik atau ada hubungan yang signifikan antara variabel dependen yaitu sarana air bersih dengan kejadian diare pada balita di Wilayah Kerja Puskesmas I Kembaran. Dan penyimpanan makanan dan minuman dengan nilai P-value : 0,003 lebih kecil dari $\alpha: 0,05$ dan nilai RP : 8,058 maka dinyatakan bermakna secara statistik atau ada hubungan yang signifikan antara variabel dependen yaitu penyimpanan makanan dan minuman dengan kejadian diare pada balita di Wilayah Kerja Puskesmas I Kembaran. Hasil analisis multivariat di atas juga menunjukkan bahwa faktor yang paling berpengaruh terhadap kejadian diare pada balita di Wilayah Kerja Puskesmas I Kembaran adalah sarana air bersih dengan nilai Rasio Prevalensi (RP) sebesar 10,663.Berdasarkan pengamatan dilapangan, sarana air bersih yang digunakan oleh responden adalah 100 $\%$ menggunakan sumur gali. Sebagian besar sumur gali yang tidak memenuhi syarat karena ada jamban 
dalam radius $<10 \mathrm{~m}$ dari sumur gali, ada sumber pencemar lain seperti kotoran hewan, sampah dalam radius $<10 \mathrm{~m}$ dari sumur gali, pembuangan air yang buruk yang menyebabkan air tidak mengalir dalam radius $<2 \mathrm{~m}$ dari sumur, letak tempat lebih rendah dari sumber pencemar, konstruksi lantai tidak kedap air sehingga dapat terjadi rembesan dan mencemari sumur, bibir sumur retak dan bocor, dinding sumur tidak kedap air, terdapat retakan pada lantai beton disekeliling sumur, tali dan ember diletakkan dengan posisi yang memungkinkan akan kotor atau memungkinkan tercemar.

Sebagai salah satu upaya untuk mencegah diare, disarankan sebaiknya masyarakat memperbaiki kondisi fisik sumur gali dengan bangunan permanen, meliputi:

1) Dinding sumur kedap air dengan tinggi miniml 3 meter dari permukaan tanah. Hal ini bertujuan untuk mencegah adanya perembesan air yang telah tercemar ke dalam sumur. Kedalaman 3 meter diambil karena bakteri pada umumnya tidak dapat hidup lagi

2) Bibir sumur kedap air dengan tinggi 1 meter dari permukaan lantai

3) Kontruksi lantai kedap air (dikeramik/diplester) dibuat menggunakan semen dengan perbandingan $1: 2$

4) Adanya saluran pembuangan air limbah yang kedap air ke arah pengolahan air buangan atau peresapan.

\section{Kesimpulan}

Berdasarkan hasil penelitian dan pembahasan dapat disimpulkan bahwa : Sarana air bersih yang digunakan responden pada kelompok kasus yang paling banyak yaitu tidak memenuhi sayarat sejumlah $13(59,1 \%)$ dan pada kelompok kontrol yang paling banyak yaitu memenuhi syarat sejumlah 41 (93,2\%). Sarana pembuangan tinja (jamban) yang digunakan responden pada kelompok kasus yang paling banyak yaitu tidak memenuhi sayarat sejumlah $15(68,2 \%)$ dan pada kelompok kontrol yang paling banyak yaitu memenuhi syarat sejumlah $37(84,1 \%)$. Sarana pembuangan air limbah yang digunakan responden pada kelompok kasus yang paling banyak yaitu tidak memenuhi sayarat sejumlah $19(86,4 \%)$ dan pada kelompok kontrol yang paling banyak yaitu tidak memenuhi syarat sejumlah $40(93,2 \%)$. Penyimpanan makanan dan minuman yang digunakan responden pada kelompok kasus yang paling banyak yaitu tidak memenuhi sayarat sejumlah $16(72,7 \%)$ dan pada kelompok kontrol yang paling banyak yaitu peneliti menyarankan untuk masyarakat sebaiknya memperbaiki dan memperhatikan persyaratan konstruksi fisik sarana air bersih sesuai persyaratan sanitasi untuk mengurangi pencemaran sumber air bersih, seperti membangun sumur dengan lantai kedap air mengguakan semen (diplester). Menggunakan jamban leher angsa dengan septic tank sebagai sarana buang air besar, menyimpan makanan pada lemari khusus untuk makanan, tertutup dan dalam kondisi bersih agar terlindung dari lalat, kecoa dan tikus, serta bahan pencemar lain, menyimpan air yang telah dimasak dalam wadah yang tertutup dan dalam keadaan bersih, meningkatkan tindakan pencegahan terjadinya diare dengan menjaga kebersihan lingkungan dan menerapkan perilaku hidup bersih dan sehat (PHBS) dalam kehidupan sehari - hari, seperti perilaku menggunakan air bersih untuk kebutuhan sehari- hari, perilaku membuang tinja bayi pada jamban yang saniter dan perilaku melakukan kebiasaan cuci tangan pakai sabun dengan air yang mengalir setelah buang air besar, sebelum dan sesudah makan, sebelum dan sesudah menyuapi balita, setelah menceboki balita dan sebelum menyiapkan makanan. Dan untuk Instansi Kesehatan sebaiknya meningkatkan kerjasama yang lebih baik lagi dari pihak Puskesmas I Kembaran dan Dinas Kesehatan Kabupaten Banyumas dengan masyarakat untuk melaksanakan penyuluhan secara berkesinambungan dari petugas (promkes/sanitarian) tentang faktor risiko yang berpengaruh pada kejadian diare, agar masyarakat mengetahui faktor risiko apa saja yang dapat mempengaruhi penularan penyakit diare pada balita dan mengubah perilaku hidup bersih dan sehat agar terhindar dari berbagai penyakit, serta mengadakan kerja sama antara Puskesmas dengan PerguruanTingga atau dengan Program Nasional Pemberdayaan Masyarakat Mandiri (PNPM Mandiri) untuk akses jamban sehat dan sarana air bersih.memenuhi syarat sejumlah $37 \quad(84,1 \%)$. Perilaku kebiasaan menggunakan air bersih untuk kebutuhan sehari - hari pada kelompok kasus dengan kategori baik dan tidak baik memiliki jumlah yang sama yaitu $11(50,0 \%)$ dan pada kelompok kontrol yang paling banyak yaitu perilaku menggunakan air bersih dengan kategori baik sejumlah 39 (88,6\%). Perilaku kebiasaan membuang tinja bayi pada kelompok kasus paling banyak yaitu dengan kategori tidak baik sejumlah $15(68,2 \%)$ dan pada kelompok kontrol yang paling banyak yaitu perilaku membuang tinja bayi dengan kategori baik sejumlah 34 (77,3\%). Perilaku kebiasaan cuci tangan pakai sabun pada kelompok kasus paling banyak yaitu dengan kategori baik sejumlah $13(59,1 \%)$ dan pada kelompok kontrol yang paling banyak yaitu perilaku cuci tangan pakai sabun dengan kategori baik sejumlah 40 (90,9\%).

Ada hubungan antara sarana air bersih dengan kejadian diare pada balita di wilayah Kerja Puskesmas I Kembaran Kabupaten Banyumas (Pvalue $=0,000: \mathrm{OR}=19,741)$. Ada hubungan antara sarana pembuangan tinja (jamban) dengan kejadian 
diare pada balita di wilayah Kerja Puskesmas I Kembaran Kabupaten Banyumas (P-value $=0,000$ : OR $=11,327)$. Tidak ada hubungan antara sarana pembuangan air limbah dengan kejadian diare pada balita di wilayah Kerja Puskesmas I Kembaran Kabupaten Banyumas (P-value $=0,888$ : OR = $0,633)$. Ada hubungan antara penyimpanan makanan dan minuman dengan kejadian diare pada balita di wilayah Kerja Puskesmas I Kembaran Kabupaten Banyumas ( $\mathrm{P}$-value $=0,000: \mathrm{OR}=14,095)$. Ada hubungan antara perilaku menggunakan air bersih unruk kebutuhan sehari - hari dengan kejadian diare pada balita di wilayah Kerja Puskesmas I Kembaran Kabupaten Banyumas (P-value $=0,002: \mathrm{OR}=7,800$ )
Ada hubungan antara perilaku membuang tinja bayi dengan kejadian diare pada balita di wilayah Kerja Puskesmas I Kembaran Kabupaten Banyumas (Pvalue $=0,001:$ OR $=7,286)$. Ada hubungan antara perilaku cuci tangan pakai sabun dengan kejadian diare pada balita di wilayah Kerja Puskesmas I Kembaran Kabupaten Banyumas (P-value = 0,006 : $\mathrm{OR}=6,923)$. Ada pengaruh secara bersama - sama antara sarana air bersih $(\mathrm{P}$-value $=0,003: \mathrm{RP}=$ 10,663) dan penyimpanan makanan dan minuman (Pvalue $=0,003: \mathrm{RP}=8,058)$ terhadap kejadian diare pada balita di wilayah Kerja Puskesmas I Kembaran Kabupaten Banyumas.

\section{Daftar Pustaka}

Ardi. 2013. Pengertian Diare. http://www.ejurnal.com/2013/04/pengertian-diare.html, diakses pada tanggal 13 Oktober 2017, Pukul 16.21 WIB

Aris Santjaka. 2011. Statistik untuk Penelitian Kesehatan 1. Yogyakarta : Nuha Medika

Buchari Lapau. 2015. Metodologi Penelitian Kebidanan Panduan Penulisan Protokol dan Laporan Hasil Penelitian.Jakarta : Yayasan Pustaka Obor Indonesia.

Depkes RI. 2000. Buku Pedoman Pelaksanaan Program P2 Diare.Jakarta : Depkes RI. . 2004. Syarat-syarat jamban Sehat. Jakarta : Departemen Kesehatan RI. 2007. Informasi pengendalian penyakit dan penyehatan lingkungan. Jakarta : Dirjen P2PL.

Dinas Kesehatan Kabupaten Banyumas. 2015. Profil Kesehatan Kabupaten Banyumas 2014. Purwokerto : Dinas Kesehatan Kabupaten Banyumas.

Dinas Kesehatan Provinsi Jawa Tengah . 2015. Profil Kesehatan Provinsi Jawa Tengah. Semarang : Dinas Kesehatan Provinsi Jawa Tengah.

Faizal Ayun Saefurahman. 2015. Hubungan Sanitasi Lingkungan Dan PHBS Dengan Kejadian Diare Pada Balita Di Desa Kebume Wilayah Kerja Puskesmas I Baturraden Tahun 2015 [KTI].Purwokerto : Poltekkes Kemenkes Semarang.

Firdaus J. Kunoli. 2013. Epidemiologi Penyakit Menular. Jakarta: CV. Trans Info Media.

http://promkes.depkes.go.id/wpcontent/uploads/pdf , diakses pada tanggal 13 Januari 2018, Pukul12.17 WIB

KESMAS.2015. Faktor Penjamu dan Lingkungan Pada Penyakit Diare.http://www.indonesianpublichealth.com/epidemiologi-penyakitdiare/, diakses pada tanggal 18 Oktober 2017, Pukul 19.07 WIB Bersih.http://www.indonesianpublichealth.com/syarat-sarana-penyediaanair-bersih/, diakses pada tanggal 21 Oktober 2017, Pukul 14.49 WIB

Kemenkes RI. Badan Penelitian dan Pengembangan Kesehatan 2013.Riset Kesehatan Dasar RISKESDAS 2013. Jakarta : Kementerian Kesehatan RI.

Buletin Diare, Tentang Situasi Diare Di Indonesia. Jakarta : Kementerian Kesehatan RI.

Direktorat Jenderal Pengendalian Penyakit Dan Penyehatan Lingkungan (Ditjen. PP \& PL), 2011a. Buku Pedoman Pengendalian Penyakit Diare. Jakarta : Ditjen PP \& PL.

. 2011a. Situs Diare Di Indonesia.Jakarta : Kementerian Kesehatan RI. 2014b. Peratura Menteri Kesehatan RI Nomor 3 Tahun 2014 Tentang Sanitasi Total Berbasis Masyarakat.Jakarta : Kementerian Kesehatan RI. https://peraturan.bkpm.go.id/jdih/userfiles/bat ang/Permenkes_3_2014.pdf, diakses pada tanggal 20 Oktober 2017, Pukul12.39 WIB

Nandini Swisza Suhartono. 2017. Hubungan Faktor Sanitasi Lingkungan Dengan Kejadian Diare Pada Balita Di Wilayah Kerja Puskesmas Pejagoan Kabupaten Kebumen Tahun 2017 [skripsi]. Purwokerto : Poltekkes Kemenkes Semarang.

Puskesmas I Kembaran. 2017. Data Diare Tahun 2016. Banyumas : Puskesmas I Kembaran.

Puskesmas I Kembaran. 2017. Profil Kesehatan Puskesmas I Kembaran 2016. Purwokerto : Puskesmas I Kembaran.

Rusbandini Warastuti. 2016. Hubungan Kondisi dan Perilaku Pemanfaatan Sanitasi Dasar Dengan 


\section{BUIFTIN GMAS}

Kejadian Diare Pada Balita Di Desa Kecila Kecamatan Kemranjen Kabupaten BanyumasTahun 2016 [skripsi].Purwokerto : Poltekkes Kemenkes Semarang.

Sekar Sari Dewi Anggreyni. 2016. Hubungan Faktor Lingkungan Dengan Kejadian Diare Pada Balita Di Desa Pasir Wetan Kecamatan Karanglewas Kabupaten Banyumas Tahun 2016 [skripsi]. Purwokerto : Poltekkes Kemenkes Semarang.

Soekidjo Notoatmodjo. 2010. Metodologi Penelitian Kesehatan Edisi revisi Cetakan Kedua.Jakarta : PT Rineka Cipta.

Soeparman,Suparmin. 2001. Pembuangan Tinja dan Limbah Cair. Jakarta:EGC

Sofyan Ismael. 1995. Dasar - Dasar Metodologi Penelitian Klinis.jakarta : Universitas Indonesia

Sugiharto. 2008. Dasar-dasar Pengolahan Air Limbah. Jakarta: UI-Press.

Sutanto Priyo Hastono, Luknis Sabri. 2011. Statistik Kesehatan. Jakarta : Rajawali Pers

Suyono dan Budiman. 2010. Ilmu Kesehatan Masyarakat Dalam Konteks Kesehatan Lingkungan. Jakarta : EGC.

Taty.2012. Sanitasi Saluran Pembuangan Air Limbah. https://tatyalfiah.wordpress.com/2012/01/22/saluranpembuangan-air-limbah-spal/. Diakses pada tanggal 30 April 2018, Pukul 08.05 WIB
Tri Asih Widiastuti. 2016. Hubungan Faktor Lingkungan Dengan Kejadian Diare Pada Balita Di Desa Sumbang Kecamatan Sumbang Kabupaten Banyumas Tahun 2016 [skripsi]. Purwokerto : Poltekkes Kemenkes Semarang.

Tri Cahyono. 2018. Panduan Penulisan Skripsi. Purwokerto : Politeknik Kesehatan kemenkes Semarang Jurusan Kesehatan Lingkungan.

Umiati. 2009. Hubungan Antara Sanitasi Lingkungan Dengan Kejadian Diare Pada Balita Di Wilayah Kerja Puskesmas Nogosari Kabupaten Boyolali Tahun 2009 [skripsi]. Surakarta : Universitas Muhammadiyah Surakarta.

Widjaja MC. 2002.Mengatasi Diare dan Keracunan Pada Balita.Jakarta : Kawan Pustaka

Widoyono. 2008. Penyakut Tropis Epidemiologi, Penularan, Pencegahan dan Pemberantasannya. Surabaya : Erlangga

Winenti. 2016. Hubungan Pencemaran Sumber Air Dan Perilaku Ibu Dengan Kejadian Diare Pada Anak Balita Di Desa Sirkandi Kecamatan Purworejo Klampok Kabupaten Banjarnegara Tahun 2016 [skripsi]. Purwokerto : Politeknik Kesehatan kemenkes Semarang Jurusan Kesehatan Lingkungan. 